OPEN ACCESS

Edited by:

Gregory D. Funk,

University of Alberta, Canada

Reviewed by:

Colin A. Nurse,

McMaster University, Canada

Christopher Wyatt,

Wright State University,

United States

*Correspondence:

Patricia Ortega-Sáenz gortega1@us.es

José López-Barneo

Ibarneo@us.es

Specialty section:

This article was submitted to

Respiratory Physiology,

a section of the journal

Frontiers in Physiology

Received: 07 October 2020 Accepted: 03 November 2020 Published: 23 November 2020

Citation:

Ortega-Sáenz $P$

Moreno-Domínguez $A$, Gao $L$ and López-Barneo J (2020) Molecular

Mechanisms of Acute Oxygen

Sensing by Arterial Chemoreceptor

Cells. Role of Hif $2 \alpha$.

Front. Physiol. 11:614893.

doi: 10.3389/fphys.2020.614893

\section{Molecular Mechanisms of Acute Oxygen Sensing by Arterial Chemoreceptor Cells. Role of Hif2 $\alpha$}

\author{
Patricia Ortega-Sáenz ${ }^{1,2,3 *}$, Alejandro Moreno-Domínguez ${ }^{1,2}$, Lin Gao $^{1,2,3}$ and \\ José López-Barneo ${ }^{1,2,3 *}$ \\ IInstituto de Biomedicina de Sevilla (IBiS), Hospital Universitario Virgen del Rocío/CSIC/Universidad de Sevilla, Seville, Spain, \\ ${ }^{2}$ Departamento de Fisiología Médica y Biofísica, Facultad de Medicina, Universidad de Sevilla, Seville, Spain, ${ }^{3}$ Centro de \\ Investigación Biomédica en Red sobre Enfermedades Neurodegenerativas (CIBERNED), Madrid, Spain
}

Carotid body glomus cells are multimodal arterial chemoreceptors able to sense and integrate changes in several physical and chemical parameters in the blood. These cells are also essential for $\mathrm{O}_{2}$ homeostasis. Glomus cells are prototypical peripheral $\mathrm{O}_{2}$ sensors necessary to detect hypoxemia and to elicit rapid compensatory responses (hyperventilation and sympathetic activation). The mechanisms underlying acute $\mathrm{O}_{2}$ sensing by glomus cells have been elusive. Using a combination of mouse genetics and single-cell optical and electrophysiological techniques, it has recently been shown that activation of glomus cells by hypoxia relies on the generation of mitochondrial signals (NADH and reactive oxygen species), which modulate membrane ion channels to induce depolarization, $\mathrm{Ca}^{2+}$ influx, and transmitter release. The special sensitivity of glomus cell mitochondria to changes in $\mathrm{O}_{2}$ tension is due to Hif $2 \alpha$-dependent expression of several atypical mitochondrial subunits, which are responsible for an accelerated oxidative metabolism and the strict dependence of mitochondrial complex IV activity on $\mathrm{O}_{2}$ availability. A mitochondrial-tomembrane signaling model of acute $\mathrm{O}_{2}$ sensing has been proposed, which explains existing data and provides a solid foundation for future experimental tests. This model has also unraveled new molecular targets for pharmacological modulation of carotid body activity potentially relevant in the treatment of highly prevalent medical conditions.

Keywords: carotid body, glomus cells, acute $\mathrm{O}_{2}$ sensing, electron transport chain, mitochondrial signaling, ion channels, mechanism of disease, paraganglioma

\section{INTRODUCTION}

Oxygen $\left(\mathrm{O}_{2}\right)$ is essential for survival of mammalian cells due to its role in numerous biochemical reactions, in particular, in mitochondrial ATP synthesis by oxidative phosphorylation. $\mathrm{O}_{2}$ deficiency (hypoxia), even if transient, can produce irreversible cellular damage. Chronic and acute adaptive responses to hypoxia have evolved to favor $\mathrm{O}_{2}$ homeostasis. Sustained (chronic) hypoxia, lasting hours or days, induces a powerful and generalized transcriptional response characterized by the expression of a broad cohort of genes that, among other changes, favors 
glycolysis, to obtain non-aerobically ATP, as well as angiogenesis and increased red blood cell number to enhance the $\mathrm{O}_{2^{-}}$ carrying capacity of the blood and its distribution to the tissues. Modulation of $\mathrm{O}_{2}$-sensitive genes depends on a family of prolyl hydroxylases (PHD), which use $\mathrm{O}_{2}$ as a substrate to hydroxylate and regulate the activity of hypoxia inducible transcription factors (HIFs; see for a recent comment LopezBarneo and Simon, 2020). To date, the PHD-HIF signaling pathway has been reported to modulate over 2,000 transcripts, many of them critically involved in numerous pathophysiological processes such as embryogenesis, stem cell fate and differentiation, tissue regeneration, inflammation and cancer, among others (Ratcliffe, 2013; Semenza, 2014; Colgan et al., 2020).

Exposure to hypoxia, as it occurs in high altitude or in patients with altered gas exchange in the lungs, also induces acute adaptive responses (hyperventilation and sympathetic activation) that in few seconds increase $\mathrm{O}_{2}$ uptake and its distribution to tissues. These life-saving cardiorespiratory reflexes are mediated by specialized cells in the homeostatic acute $\mathrm{O}_{2}$ sensing system (Weir et al., 2005). The prototypical acute $\mathrm{O}_{2}$ sensing organ is the carotid body (CB), a small arterial chemoreceptor located in the carotid bifurcation, which contains chemosensory and neurosecretory glomus cells (Figure 1A).
Glomus cells release transmitters during exposure to hypoxia and other stimuli to activate afferent fibers of the glossopharyngeal nerve terminating at the brainstem respiratory and autonomic centers. Although it is over 30 years that the basic cellular physiology of the $\mathrm{CB}$ was described (see for a recent review Ortega-Saenz and Lopez-Barneo, 2020), the molecular mechanism underlying acute $\mathrm{O}_{2}$-sensing by glomus cells has remained elusive. Among the several attractive hypotheses postulated are the involvement of a specific NADPH oxidase, activation of AMP kinase during hypoxia, the reversible fast regulation of ion channels by gasotransmitters such as carbon monoxide and hydrogen sulfide, or the expression of an atypical olfactory receptor (Olfr78; see for recent reviews Lopez-Barneo et al., 2016; Rakoczy and Wyatt, 2018). Although all these processes can influence glomus cell function, none of them seem to be essential for acute $\mathrm{O}_{2}$ sensing because the various mouse models generated after ablation of the genes coding the relevant enzymes or receptors showed $\mathrm{CB}$ with practically normal responsiveness to hypoxia (He et al., 2002; Ortega-Saenz et al., 2006; Mahmoud et al., 2016; Wang et al., 2017; Torres-Torrelo et al., 2018). It has recently been reported that Olfr78-deficient CB cells have decreased responsiveness to mild hypoxia (Peng et al., 2020). Olfr78 is one of the most
A

D

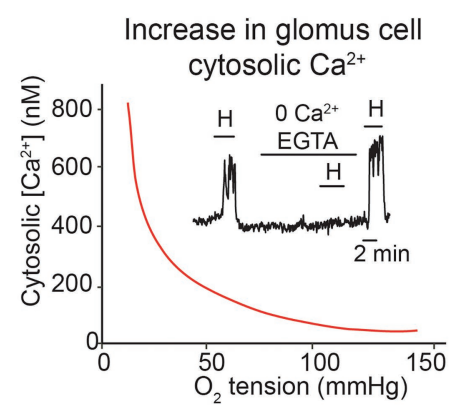

B

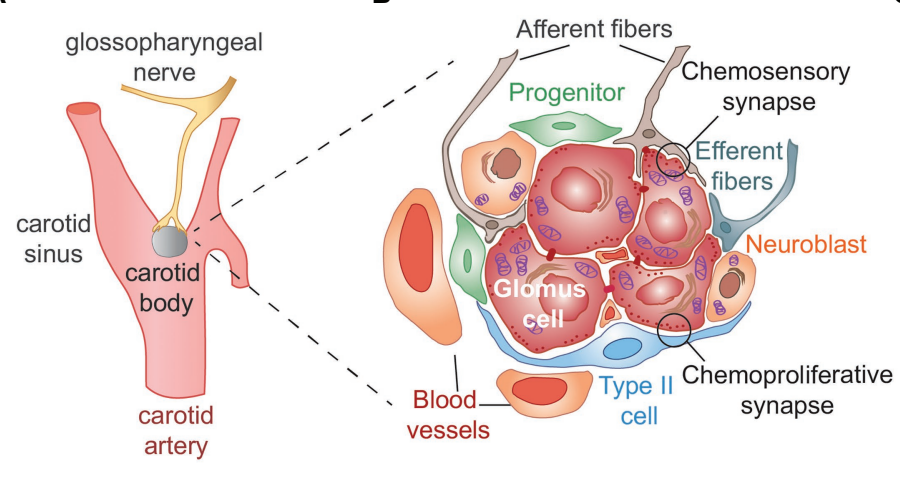

Afferent fibers

E

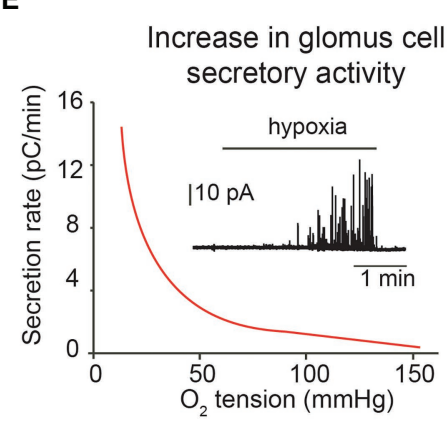

C

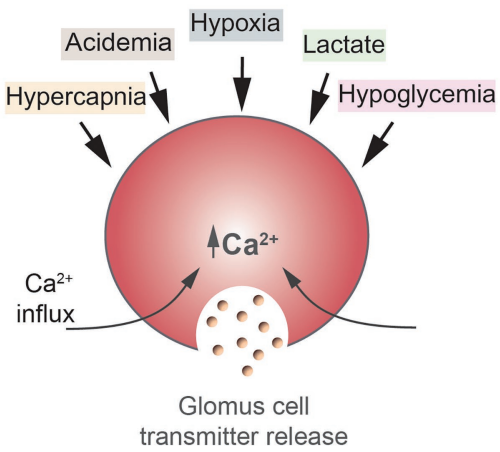

F

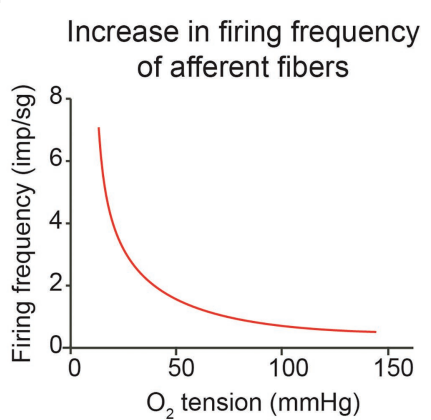

FIGURE 1 | Structural and functional properties of carotid arterial chemoreceptors. (A) Location and innervation of the carotid body (CB). (B) Schematic representation of a CB glomerulus with indication of the various structural components and cell types. (C) Schematic representation of $\mathrm{CB}$ glomus cell activation by several stimuli. (D,E) Hyperbolic relationships between cytosolic $\mathrm{Ca}^{2+}$ (inset in $\mathbf{D}$ ) and catecholamine release (inset in $\mathbf{E}$ ) in single glomus cells as a function of oxygen tension in the external solution. Hypoxia-induced increase in cytosolic $\mathrm{Ca}^{2+}$ depends on extracellular $\mathrm{Ca}^{2+}$ influx (D). (F) Relationship between firing frequency in afferent fibers of the sinus nerve as a function of blood oxygen tension. (A-C) Modified from Ortega-Saenz and Lopez-Barneo (2020). (D,E) Modified from Montoro et al. (1996) and Ortega-Saenz et al. (2006). (F) Modified from Lopez-Barneo (1996). 
abundant mRNA species expressed in CB glomus cells (Zhou et al., 2016; Gao et al., 2017), as other highly expressed G-protein-coupled receptors, which may influence the input/ output properties of chemoreceptor cells (Nurse, 2014; OrtegaSaenz and Lopez-Barneo, 2020). In recent years new experimental data have provided strong support for a "mitochondrial-to-membrane signaling (MMS) model" of acute $\mathrm{O}_{2}$ sensing, which combines the "membrane" and "metabolic" hypotheses. Here, after a succinct presentation of the general properties of $\mathrm{CB}$ glomus cells, we focus on the description of the MMS model of acute $\mathrm{O}_{2}$ sensing. We also discuss the potential medical implications of recent advances in $\mathrm{CB}$ research.

\section{PROPERTIES OF POLYMODAL CAROTID BODY CHEMORECEPTOR CELLS}

The $\mathrm{CB}$ is organized in clusters of cells called glomeruli. Each glomerulus contains neuron-like and tyrosine hydroxylase (TH)-positive glomus (or type I) cells, which appear grouped (normally 4-8 units) in the center, enveloped by processes of glia-like, glial fibrillary acidic protein (GFAP)-positive, type II or sustentacular cells (Figure 1B). Glomus cells have large nuclei, abundant mitochondria, and numerous secretory vesicles, containing dopamine, ATP, acetylcholine, and several other neurotransmitters and neuropeptides. These cells establish chemical synapses with afferent fibers ("chemosensory synapses"; Figure 1B) originating in the petrosal ganglion. It is wellestablished that the main transmitter in the chemosensory synapse is ATP, which binds to postsynaptic P2X receptors, although acetylcholine may also have a stimulatory effect (Zhang et al., 2000; Rong et al., 2003; Shirahata et al., 2007). Dopamine has an auto or paracrine role inhibiting $\mathrm{Ca}^{2+}$ channels in glomus cells (Benot and Lopez-Barneo, 1990) and, in addition, it can also inhibit postsynaptic $\mathrm{HCH}$ cationic channels in petrosal afferent neuros via D2 receptors (Zhang et al., 2018). Although mature $\mathrm{O}_{2}$-sensitive glomus cells seem to be post-mitotic, the $\mathrm{CB}$ also contains a population of immature TH-positive cells, normally localized in the periphery of the glomerulus, with fewer secretory vesicles and smaller sensitivity to hypoxia than mature glomus cells (Sobrino et al., 2018). In hypoxic conditions, these TH-positive "neuroblasts" proliferate and differentiate into mature glomus cells and in this way contribute to adult $\mathrm{CB}$ growth, a plastic $\mathrm{CB}$ response that increases the stimulatory input to the respiratory center and thereby facilitates chronic adaptation to hypoxic environments. Glomus cells also establish numerous chemical synapses with type II cells (Platero-Luengo et al., 2014). Indeed, transmitters released from glomus cells can induce ATP release from type II cells to potentiate the chemosensory synapse (Xu et al., 2003; Zhang et al., 2012). GFAP-positive type II cells, or a subpopulation of them, are quiescent multipotent stem cells that upon exposure to hypoxia are activated to proliferate and differentiate into new glomus cells, endothelial cells, and smooth muscle (Pardal et al., 2007; Navarro-Guerrero et al., 2016; Annese et al., 2017). Glomus cells and type II cells form "chemoproliferative synapses"
(Figure 1B), such that neurotransmitters and neuromodulators (endothelin-1 among others) released from glomus cells (Chen et al., 2002) induce type II cells to exit the quiescent state and to start proliferating and differentiating (Platero-Luengo et al., 2014). Therefore, the adult CB is a sophisticated germinal niche that contains differentiated cells with complex sensory functions, as well as immature neuroblasts and progenitors with strong neurogenic and angiogenic potential that support the structural plasticity of the organ.

Chemosensory glomus cells are small $(\sim 10-15 \mu \mathrm{m}$ in diameter) and electrically compact elements able to generate action potentials repetitively due to the expression of voltage-gated $\mathrm{Na}^{+}, \mathrm{Ca}^{2+}$, and $\mathrm{K}^{+}$channels. They also express a broad spectrum of other ion channels types, notably background $\mathrm{K}^{+}$channels, in particular, TASK1 and TASK 3 channels, and cationic TRP channels (Zhou et al., 2016; Gao et al., 2017). It is established that hypoxia produces glomus cell depolarization due to the inhibition of background and voltage-gated $\mathrm{K}^{+}$channels; this leads to the opening of voltage-dependent $\mathrm{Ca}^{2+}$ channels, extracellular $\mathrm{Ca}^{2+}$ influx, and exocytotic transmitter release (Lopez-Barneo et al., 1988; Buckler and Vaughan-Jones, 1994; Urena et al., 1994). It has also been reported that the rise in intracellular $\mathrm{Ca}^{2+}$ can activate $\mathrm{Ca}^{2}$-permeant background cation channels to further potentiate $\mathrm{Ca}^{2+}$ entry and transmitter release (Kang et al., 2014). In addition to hypoxia, glomus cells are activated by hypercapnia, low extracellular $\mathrm{pH}$, low glucose, and lactate as well as by hypoperfusion and several circulating hormones and cytokines. Although these stimuli utilize separate transduction mechanisms, they all converge on extracellular $\mathrm{Ca}^{2+}$ influx and the generation of a cytosolic $\mathrm{Ca}^{2+}$ signal that triggers transmitter release (see for a recent review Ortega-Saenz and Lopez-Barneo, 2020). The $\mathrm{CB}$, classically considered to be fundamentally involved in the regulation of respiration, is now viewed as a polymodal arterial chemoreceptor needed for optimal regulation of metabolism and homeostasis of the organism (Figure 1C).

\section{MITOCHONDRIA-TO-MEMBRANE SIGNALING MODEL OF ACUTE OXYGEN SENSING}

Acute responsiveness to hypoxia is an intrinsic property of glomus cells that is maintained in in vitro preparations such as dispersed cells, CB slices, or glomus cell-petrosal neuron synapse (Lopez-Barneo et al., 1988; Peers, 1990; Buckler and Vaughan-Jones, 1994; Zhong et al., 1997; Pardal et al., 2000). The curves relating cytosolic $\mathrm{Ca}^{2+}$ level or single glomus cell catecholamine secretion as a function of $\mathrm{O}_{2}$ tension $\left(\mathrm{PO}_{2}\right)$ are remarkably similar to the hyperbolic relationship existing between afferent $\mathrm{CB}$ sensory activity and arterial $\mathrm{PO}_{2}$ (Figures 1D-F). Although the membrane events - depolarization and extracellular $\mathrm{Ca}^{2+}$ influx- underlying glomus cell responsiveness to hypoxia (known as the "membrane hypothesis") are broadly accepted, mitochondria have also been classically considered to be involved in $\mathrm{CB} \mathrm{O}_{2}$ sensing. A "metabolic hypothesis" was supported by the high sensitivity of $\mathrm{CB}$ to mitochondrial poisoning and the fact that mitochondrial inhibitors are powerful CB stimulants. 
Indeed, the existence in the $\mathrm{CB}$ of a special cytochrome $\mathrm{c}$ oxidase with low $\mathrm{O}_{2}$ affinity was proposed several decades ago, although it was placed in type II rather than in type I cells (Mills and Jobsis, 1972). This idea of a mitochondrial $\mathrm{O}_{2}$ sensor was further suggested by the analysis of lightdependent interaction of $\mathrm{CO}$ with heme proteins in CB cells, although as the experiments were performed in whole $\mathrm{CB}$ preparations, the precise cellular location of the sensor was not determined precisely (Wilson et al., 1994). In addition, Duchen and Biscoe (1992a,b) showed that in dispersed CB glomus cells mitochondrial parameters (e.g., NADH level or mitochondrial membrane potential) are highly sensitive to changes in ambient $\mathrm{PO}_{2}$, thereby strongly supporting the "metabolic hypothesis." However, these last authors proposed that $\mathrm{Ca}^{2+}$ release from mitochondria was the signal to trigger hypoxia-induced transmitter release, a conclusion that was in direct opposition to the well-established dependence of hypoxic glomus cell activation on extracellular $\mathrm{Ca}^{2+}$ influx (Lopez-Barneo et al., 1993; Buckler and Vaughan-Jones, 1994; Urena et al., 1994).

\section{Acute $\mathrm{O}_{2}$ Sensing Depends on Mitochondrial Complex I Signaling}

The first step to resolve to conflict between the "membrane" and "metabolic" hypotheses came from experiments on PC12 cells (an $\mathrm{O}_{2}$-sensitive catecholaminergic cell line; Taylor et al., 2000) and carotid body slices (Ortega-Saenz et al., 2003) showing that, as it occurs with hypoxia, catecholamine secretion induced by mitochondrial electron transport chain (ETC) inhibitors acting on complexes I, II, III, and IV is fully abolished by removal of extracellular $\mathrm{Ca}^{2+}$ or administration of $0.2 \mathrm{mM}$ $\mathrm{Cd}^{2+}$, a non-selective voltage-gated $\mathrm{Ca}^{2+}$ channel blocker (Urena et al., 1994). Separate experiments showed that ETC blockers also inhibit the $\mathrm{O}_{2}$-sensitive background $\mathrm{K}^{+}$current in dispersed glomus cells (Wyatt and Buckler, 2004). These data on single cells are in good agreement by previous work on whole CBs showing that dopamine secretion during incubation with cyanide is strongly inhibited in the absence of extracellular $\mathrm{Ca}^{2+}$ (Obeso et al., 1989). Ortega-Saenz et al. (2003) found that rotenone, a highly selective mitochondria complex I (MCI) blocker that binds near the last $\mathrm{Fe} / \mathrm{S}$ cluster (N2 site) and prevents the transfer of electrons to ubiquinone, was very effective in occluding any effect of hypoxia. In contrast, activation of glomus cells by hypoglycemia was unaffected by rotenone (GarciaFernandez et al., 2007). These data suggested that hypoxia and hypoglycemia are sensed by separate mechanisms and that a rotenone binding site is directly involved in acute $\mathrm{O}_{2}$ sensing by glomus cells.

To investigate the role of $\mathrm{MCI}$ in acute $\mathrm{O}_{2}$ sensing, we generated conditional knockout mice lacking the Ndufs2 gene, which codes a $49 \mathrm{kDa}$ protein that contributes to the ubiquinone/rotenone binding site and is also essential for the assembly of the catalytic core in MCI (Kashani-Poor et al., 2001; Carroll et al., 2013). Because generalized bi-allelic deletion of Ndufs2 results in embryonic lethality, we generated conditional Ndufs 2 knockout mice with either ablation of $N d u f s 2$ in glomus cells and other catecholaminergic cells
(TH-NDUFS2 mice) or ubiquitous tamoxifen (TMX)-induced Ndufs2 deletion in adulthood (ESR-NDUFS2 mice). TH-NDUFS2 mice had a normal development although they had smaller size than adult wild type littermates probably due to dwarfing secondary to the loss of hypothalamic dopaminergic neurons (Diaz-Castro et al., 2012; FernandezAguera et al., 2015). At 2 months of age, these mice exhibited a loss of the hypoxic ventilatory response (HVR; Figure 2A), although they had a normal ventilatory response to hypercapnia (Fernandez-Aguera et al., 2015). CBs from TH-NDUFS2 mice appeared slightly hypertrophied and with normal structural organization. However, Ndufs2-deficient glomus cells showed an almost complete abolition of responsiveness to hypoxia (monitored by either the catecholamine secretory response or the changes in cytosolic $\left[\mathrm{Ca}^{2+}\right]$ ), while they responded normally to hypercapnia and hypoglycemia (Figure 2B). Similar results were observed in ESR-NDUFS2 mice, in which Ndufs2 deficiency was induced by TMX treatment in adulthood and exhibited an almost complete disappearance of MCI structure and function (Fernandez-Aguera et al., 2015; Arias-Mayenco et al., 2018). In contrast with the effects of Ndufs2 deficiency, ablation of the Ndufs4 gene, which codes a non-essential MCI auxiliary subunit that reduces MCI activity by approximately $50 \%$ (Kruse et al., 2008), did not cause appreciable changes in the catecholamine release and cytosolic $\mathrm{Ca}^{2+}$ responses to hypoxia in glomus cells (Fernandez-Aguera et al., 2015). These data indicated that MCI function is essential for acute $\mathrm{O}_{2}$ sensing and confirmed that hypoxia and hypoglycemia are sensed by means of separate mechanisms. Interestingly, it was found that $\mathrm{CB}$ cells contain high levels of succinate, suggesting a highly active Kreb's cycle, and that upregulation or downregulation of succinate dehydrogenase activity enhances or diminishes, respectively, sensitivity to hypoxia in glomus cells (FernandezAguera et al., 2015; Gao et al., 2017; Arias-Mayenco et al., 2018). Although glomus cells survived several months in the absence of MCI, they rapidly died after ablation of MCII (Diaz-Castro et al., 2012; Platero-Luengo et al., 2014).

Taken together, these experimental findings suggested a model of acute $\mathrm{O}_{2}$ sensing in which mitochondria, acting as a sensor and effector of the hypoxic response, modulate membrane excitability. We proposed that decreased cytochrome c oxidase activity under hypoxia causes a backlog of electrons along the ETC and an increase in the ratio of reduced/oxidized ubiquinone $\left(\mathrm{QH}_{2} / \mathrm{Q}\right)$, which results in slowing down or even reversion of $\mathrm{MCI}$ with $\mathrm{NADH}$ accumulation and reactive oxygen species (ROS) production (Figure 2C). NADH and ROS are the signals that modulate plasmalemmal ion channels to produce depolarization and activation of glomus cells. Graded accumulation of NADH in glomus cells induced by lowering $\mathrm{PO}_{2}$ was abolished in Ndufs2-deficient mice (Fernandez-Aguera et al., 2015; Arias-Mayenco et al., 2018; Figure 2D). We were also able to monitor in real time the changes in mitochondrial ROS production by means of a fluorescent genetic probe targeted to either mitochondrial intermembrane space (IMS) or matrix. Using this methodology, we demonstrated that acute hypoxia induces in glomus cells a dose-dependent increase in IMS (and cytosol) ROS, which 
A

Hypoxic ventilatory response

Wild type mice

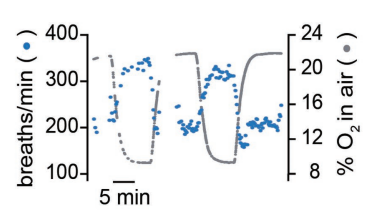

Ndufs2-deficient mice

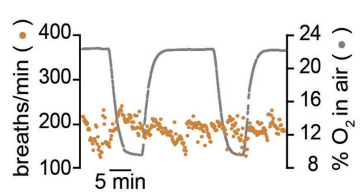

C

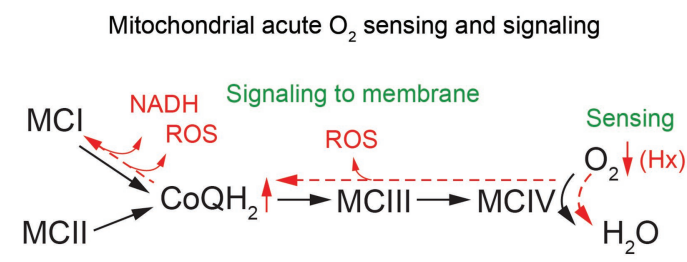

B
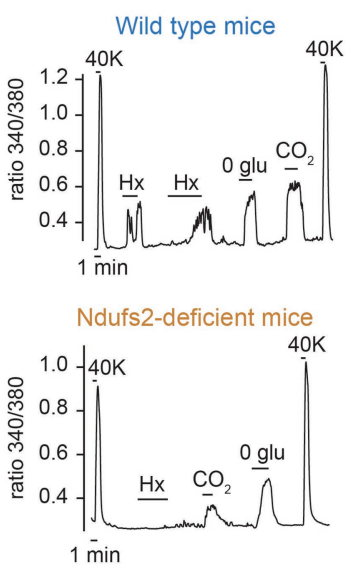
ak

E

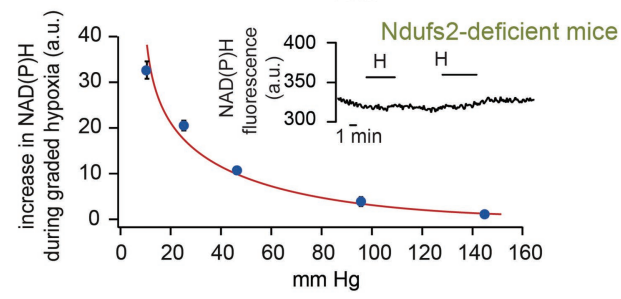

ROS intermembrane space Wild type mice

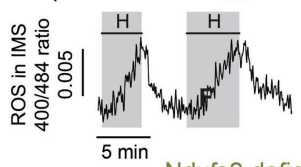

Ndufs2-deficient mice

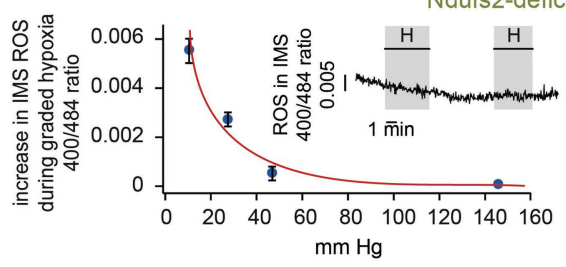

FIGURE 2 | Selective inhibition of acute oxygen sensing by arterial chemoreceptors in mitochondrial complex I (MCl)-deficient mice. (A) Ventilatory response to hypoxia in wild type (top) and Ndufs2-deficient (bottom) mice. (B) Changes in cytosolic $\mathrm{Ca}^{2+}$ in single wild type (top) and Ndufs2-deficient (bottom) glomus cells induced by depolarization $\left(40 \mathrm{mM} \mathrm{K}\right.$ ), hypoxia $(\mathrm{Hx}, \sim 15 \mathrm{~mm} \mathrm{Hg}), 0$ glucose $(0 \mathrm{glu})$, and hypercapnia (switching from 5 to $\left.10 \% \mathrm{CO}_{2}\right)$. (C) Scheme of the electron transport chain illustrating the mitochondria-to-membrane signaling model of acute $\mathrm{O}_{2}$ sensing by glomus cells. Changes in chemical equilibrium induced by hypoxia $(\mathrm{Hx})$ are represented in red. (D) Changes in NADH autofluorescence in single glomus cells from wild type and Ndufs2-deficient mice during exposure to hypoxia. Relationship between NADH levels and extracellular oxygen tension. (E) Measurement of reactive oxygen species (ROS) at the mitochondrial intermembrane space in single glomus cells from wild type and Ndufs2-deficient mice. Relationship between ROS levels and extracellular oxygen tension. Modified from Fernandez-Aguera et al. (2015) and Arias-Mayenco et al. (2018).

is markedly decreased by rotenone and in Ndufs2-deficient mice (Figure 2E). However, the possibility that IMS ROS produced in other sites along a reduced ETC (e.g., in MCIII) also contribute to the hypoxic response cannot be discarded (Figure 2C; Waypa et al., 2010). In support of the MMS model, we showed that intracellular dialysis of glomus cells with $\mathrm{NADH}$ and $\mathrm{H}_{2} \mathrm{O}_{2}$ mimic hypoxia (increase in input resistance and decrease in voltage-gated $\mathrm{K}^{+}$current amplitude) and prevents further modulation of $\mathrm{K}^{+}$channels by lowering $\mathrm{PO}_{2}$ (Fernandez-Aguera et al., 2015). Other mitochondrial signals (e.g., decrease in cytosolic ATP level restricted to $\mathrm{O}_{2}$-sensing microdomains; see below) could also contribute to modulation of membrane channels and the hypoxic response (Varas et al., 2007).

\section{Signature Gene Expression Profile in $\mathrm{O}_{2}$-Sensing Chemoreceptor Cells}

In the past decades, several groups have reported gene expression data focusing on different aspects of CB glomus cell function and, recently, two such studies provided relevant clues for advancing the understanding of glomus cell acute $\mathrm{O}_{2}$ sensing. In one case, single neonatal glomus cell RNA sequencing confirmed the constitutive high expression of $\mathrm{Hif} 2 \alpha$ and highlighted the elevated expression of two atypical mitochondrial subunits (Ndufa4l2 and Cox4i2), and several ion channels, in particular, Task1 and the low-threshold $\mathrm{Ca}^{2+}$ channel $\alpha 1 \mathrm{H}$ subunit (Zhou et al., 2016). This work also showed the high level of expression of genes coding for molecules involved in G-protein signaling, an observation compatible with the elevated number of metabotropic ligands and receptors in glomus cells. A parallel microarray study performed in our laboratory focused on the comparative expression profile of adult $\mathrm{CB}$, adrenal medulla (AM), and superior cervical ganglion (SCG), which are tissues of the same neural crest embryological origin but variable $\mathrm{O}_{2}$ sensitivity $(\mathrm{CB}>\mathrm{AM}>\mathrm{SCG})$. Our work confirmed most of the genes reported in the single-cell sequencing study mentioned above and demonstrated a set of genes highly expressed in $\mathrm{CB}$, and less markedly in the $\mathrm{AM}$, in comparison with the SCG with a potential role in acute $\mathrm{O}_{2}$ sensing (Gao et al., 2017). The most relevant genes in the $\mathrm{CB}$ signature gene expression profile code Hif $2 \alpha$, three atypical mitochondrial subunits (Ndufa4l2, Cox4i2, and Cox8b), pyruvate carboxylase (Pcx), and some types of ion channels (Task1, Task3, and the $\alpha 1 \mathrm{H} \mathrm{Ca}^{2+}$ channel subunit). In the context of the MMS model, 
it was of special relevance the identification of Pcx and the three nuclear-encoded atypical mitochondrial subunits (Ndufa412, Cox4i2, and Cox8b), which could be responsible for the special $\mathrm{O}_{2}$-sensitivity of glomus cells. In particular, the high level of Pcx mRNA expression is compatible with the accumulation of biotin, a cofactor necessary for the function of Pcx and other carboxylases, accumulated in large quantity in glomus cells (Ortega-Saenz et al., 2016). Pcx is an anaplerotic enzyme that catalyzes the formation of oxaloacetate, thereby replenishing the pool of Krebs's cycle intermediates required for an accelerated synthesis of substrates $\left(\mathrm{NADH}\right.$ and $\mathrm{FADH}_{2}$ ) for the ETC. Therefore, Pcx probably contributes to the active oxidative metabolism and high $\mathrm{O}_{2}$ consumption characteristic of $\mathrm{CB}$ cells. This idea is also compatible with the high levels of succinate found in the $\mathrm{CB}$ and the strict dependence of $\mathrm{CB}$ survival and function on succinate dehydrogenase activity (Diaz-Castro et al., 2012; Platero-Luengo et al., 2014; Fernandez-Aguera et al., 2015).

\section{Acute $\mathrm{O}_{2}$ Sensing Through Hif2 $\alpha$-Dependent Expression of Atypical Mitochondrial Complex IV Subunits}

Although it was known long ago that Hif2 $\alpha$ is constitutively expressed at high levels in normoxic catecholaminergic tissues (Tian et al., 1998), the role of this factor in CB function has not been studied until the last few years. It has been shown that transgenic overexpression of Epas1 (the gene coding Hif2 $\alpha$ ) produces CB hypertrophy (Macias et al., 2014) and embryonic ablation of Epas1 results in CB atrophy (Macias et al., 2018), thereby suggesting that Hif2 $\alpha$ is essential for CB development and function. Heterozygous (Epas1+/-) mice were reported to have an exaggerated $\mathrm{CB}$ responsiveness to hypoxia (Peng et al., 2011) but more recent experiments performed independently by two different groups have shown that these mice have a decrease in the HVR (Hodson et al., 2016; Moreno-Dominguez et al., 2020). Inhibition of the HVR is also seen in variable degrees in mice with homozygous partial (Hodson et al., 2016) or complete (Moreno-Dominguez et al., 2020) conditional deletion of Epas1 in adulthood. In agreement with these observations, glomus cells from conditional Epas1-null mice show selective abolition of the rise in cytosolic $\left[\mathrm{Ca}^{2+}\right]$ (Figure 3A, left and center) or the secretory response to hypoxia. Moreover, NADH and IMS ROS signals induced by hypoxia are strongly inhibited in Epas1-deficient glomus cells (Figures 3B,C). Interestingly, the hypoxia-induced decrease in matrix ROS (Arias-Mayenco et al., 2018) was not altered by Epas1 deficiency (Figure 3D) thereby indicating that the lack of Hif $2 \alpha$ did not change the basic mitochondria metabolism but selectively inhibited signaling in response to low $\mathrm{PO}_{2}$. In parallel with these functional data, it has been shown that abolition of Epas1 results in a selective downregulation of mRNAs coding Pcx and the atypical mitochondrial ETC subunits characteristic of CB cells (Moreno-Dominguez et al., 2020). These results are compatible with previous studies reporting that hypoxia induces Cox4i2 (Fukuda et al., 2007) and Ndufa4l2
(Tello et al., 2011) in a Hif-dependent manner (see also Aras et al., 2013), and that Cox8b promoter contains Hif binding sites (Gao et al., 2017). Together these findings indicate that the expression of Hif2 $\alpha$-dependent genes confer acute $\mathrm{O}_{2}$ responsiveness to $\mathrm{CB}$ glomus cells. Indeed, the Epas1-null phenotype (inhibition of HVR and lack of glomus cells sensitivity to hypoxia) is also observed in mice with ablation of the Cox4i2 gene in catecholaminergic cells (TH-COX4I2 mice; Figure 3A, right; Moreno-Dominguez et al., 2020).

The data reported so far provide molecular and mechanistic explanation for an MMS model of acute $\mathrm{O}_{2}$ sensing by arterial chemoreceptor cells in which cytochrome c oxidase acts as an $\mathrm{O}_{2}$ sensor that, depending on $\mathrm{O}_{2}$ availability, determines the redox state of the steps upstream in the ETC. In response to hypoxia, the increase in the reduced state of MCIII and accumulation of $\mathrm{QH}_{2}$ results in the generation of the signals (NADH and ROS) that modulate membrane ion channels (Figures 4A,B, see also Figure 2C). However, the precise role of each of the atypical MCIV subunits and how they influence acute $\mathrm{O}_{2}$ sensing in the $\mathrm{CB}$ and, possibly, other acutely responding organs, remains to be studied. Ndufa4l2, which is coded by one of the most abundant mRNA species in CB glomus cells, is an isoform of the most widely expressed Ndufa4 subunit, which appears to be associated to MCIV rather than to MCI (Carroll et al., 2006; Balsa et al., 2012). Ndufa4l2 is highly expressed in lung and brain pericytes and some tumor cells (Lucarelli et al., 2018) but its function is poorly known. Expression of Ndufa4l2 attenuates oxygen consumption and decreases ROS production in mitochondria (Tello et al., 2011; Meng et al., 2019), however ablation of the Ndufa4l2 gene did not produce any clear effect on glomus cell function or HVR (Moreno-Dominguez et al., 2020). Therefore, the precise role of Ndufa4l2 in the context of acute $\mathrm{O}_{2}$ sensing remains to be determined. On the other hand, Cox $4 \mathrm{i} 2$ and Cox $8 \mathrm{~b}$ are atypical isoforms of the more broadly distributed Cox4il and Cox8a subunits, which are part of the catalytic core of MCIV (Tsukihara et al., 1996). Besides in the CB, Cox4i2 is highly expressed in the lung and some cell types (e.g., pericytes; Huttemann et al., 2012) and Cox8b appears associated to the browning of adipose tissue (Wang et al., 2016). Interestingly, Cox4 and Cox8 subunits contain single adjacent transmembrane helices running in parallel at the periphery of MCIV (Tsukihara et al., 1996; Kadenbach and Huttemann, 2015) that, although located relatively far from the catalytic site (heme a3/CuB), could induce subtle structural changes in MCIV or in its association with supercomplexes that influence the affinity for or reaction rate with $\mathrm{O}_{2}$. Structural studies have suggested that the Cox8 subunit contributes to the formation of mitochondrial supercomplexes (Wu et al., 2016; Rieger et al., 2017) and a recent study on tumor cells lines have reported that expression of Cox4i2 (instead Cox4i1) decreases the $\mathrm{Km}$ of cytochrome c oxidase for $\mathrm{O}_{2}$ (Pajuelo Reguera et al., 2020). In this last study, the $\mathrm{Km}$ of cytochrome $\mathrm{c}$ oxidase for $\mathrm{O}_{2}$ varied between $\sim 0.5 \mathrm{~mm} \mathrm{Hg}$ (in mitochondria expressing Cox4i1) and $\sim 1 \mathrm{~mm} \mathrm{Hg}$ (in mitochondria expressing Cox4i2). These are $\mathrm{PO}_{2}$ values much lower than those necessary for activation of glomus cells, even assuming a steep $\mathrm{O}_{2}$ gradient 
A
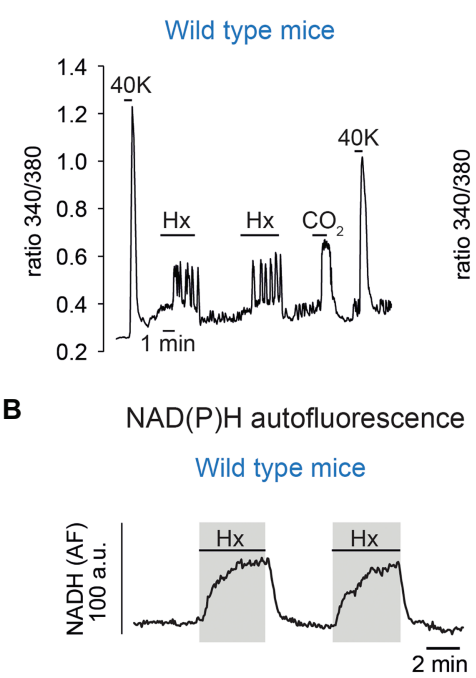

Hif2 $\alpha$-deficient mice

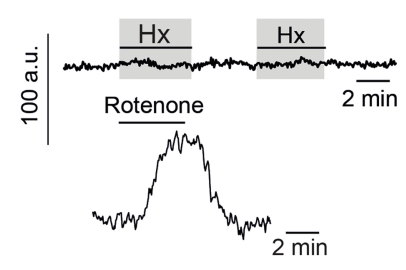

Glomus cell cytosolic $\mathrm{Ca}^{2+}$
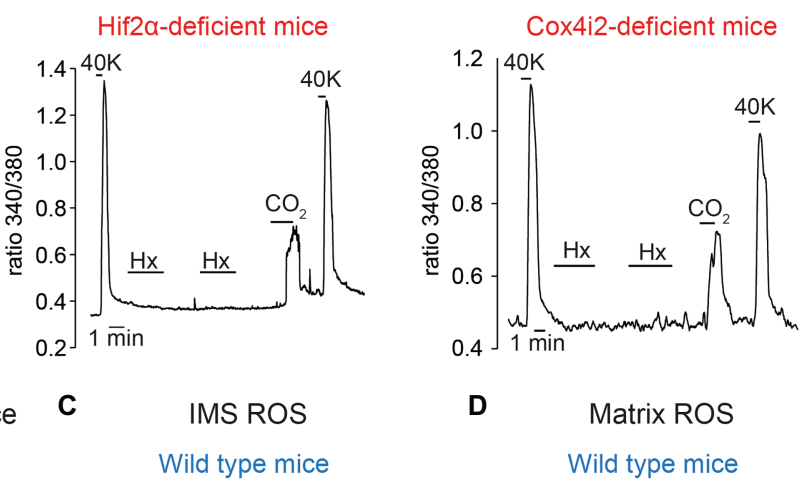

D
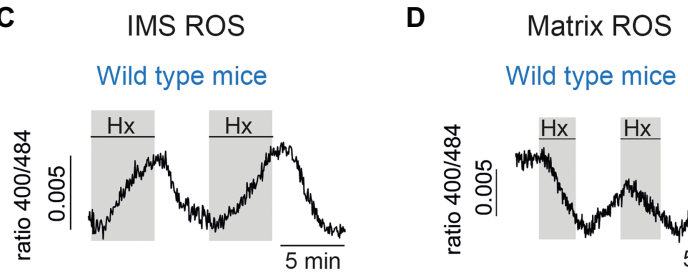

Hif2 $\alpha$-deficient mice

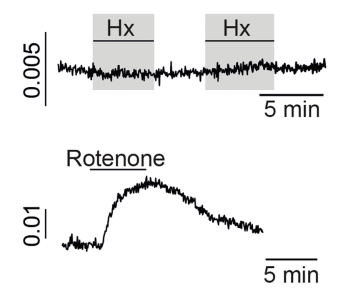

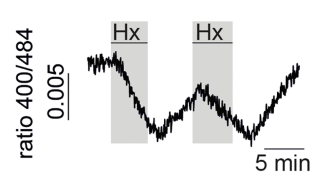

Hif2 $\alpha$-deficient mice
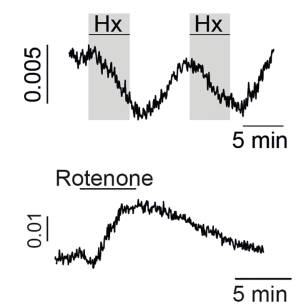

FIGURE 3 | Selective inhibition of carotid body glomus cell responsiveness to hypoxia in Hif2 $\alpha$ - and Cox4i2-deficient mice. (A) Changes in cytosolic Ca ${ }^{2+}$ in single wild type (left), Hif2 $\alpha$-deficient (center), and Cox4i2-deficient (right) glomus cells induced by depolarization ( $40 \mathrm{mM} \mathrm{K} \mathrm{K}^{+}$), hypoxia ( $\mathrm{Hx}, \sim 15 \mathrm{~mm} \mathrm{Hg}$ ), and hypercapnia (switching from 5 to $10 \% \mathrm{CO}_{2}$ ). (B) Changes in $\mathrm{NADH}$ autofluorescence in single glomus cells from wild type and Hif2 $\alpha$-deficient mice during exposure to hypoxia. (C) Measurement of ROS at the mitochondrial intermembrane space (IMS) in single glomus cells from wild type and Hif2 $\alpha$-deficient mice. (D) Measurement of ROS at the mitochondrial matrix in single glomus cells from wild type and Hif2 $\alpha$-deficient mice. In B-D, response to rotenone $(0.5-1 \mu \mathrm{M})$ was tested to show the normal function of MCl. Modified from Moreno-Dominguez et al. (2020).

between the extracellular medium and mitochondria. Therefore, it seems that in addition to the Cox 4 subunit isoforms, other factors may influence the $\mathrm{Km}$ of cytochrome c oxidase for $\mathrm{O}_{2}$ in glomus cells. In sum, the MMS model provides a satisfactory molecular explanation for acute $\mathrm{O}_{2}$ sensing by arterial chemoreceptor cells, which depends on a Hif2 $\alpha$-dependent expression of specific genes. The special $\mathrm{O}_{2}$ sensitivity of glomus cells seems to result from the combination of an accelerated ETC and $\mathrm{O}_{2}$ consumption due to an active Krebs cycle and a relatively low affinity of cytochrome c oxidase for $\mathrm{O}_{2}$. In this way, electron flux in mitochondrial ETC is modulated in a physiological range of $\mathrm{O}_{2}$ tensions. Whether an MMS model, involving similar genes and regulatory mechanisms, also participates in acute $\mathrm{O}_{2}$ sensing by other tissues remains to be studied. In this regard, it is important to note that Cox4i2deficient mice exhibit strong inhibition of hypoxic pulmonary vasoconstriction (Sommer et al., 2017), an acute response to hypoxia that, similar to hypoxic glomus cell activation, depends on the production of ROS by mitochondria and the modulation of $\mathrm{O}_{2}$-sensitive $\mathrm{K}^{+}$channels (Weir et al., 2005).

\section{CLINICAL AND PHARMACOLOGICAL IMPLICATIONS}

In recent years, the $\mathrm{CB}$ has gained renewed medical interest due to its involvement in the pathogenesis of several highly prevalent human diseases, such as neurogenic hypertension, obstructive sleep apnea, and chronic cardiac failure. In addition, CB dysfunction also contributes to the pathophysiology of respiratory depression, a frequent complication of anesthesia and drug abuse.

\section{Carotid Body Inhibition}

$\mathrm{CB}$ activation is the first line of defense against hypoxic challenges and, therefore, $\mathrm{CB}$ dysfunction may have fatal consequences. Indeed, bilateral resection of the $\mathrm{CB}$, most commonly due neck tumor surgery or asthma treatment, leaves the patients unaware of hypoxemia (Timmers et al., 2003). These patients cannot adapt to hypoxic environments and although they appear to live unaffected in normoxic conditions, disturbances during sleep and unexplained cases of death have 


\section{A}

Mitochondrial-to-membrane signaling model of acute $\mathrm{O}_{2}$ sensing

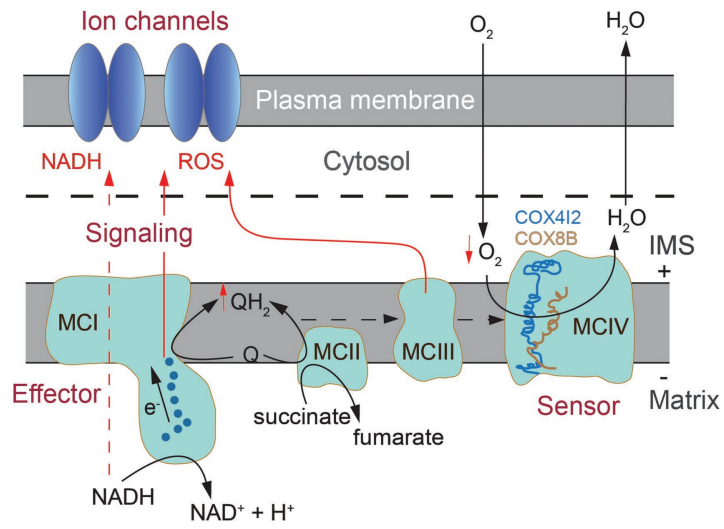

B

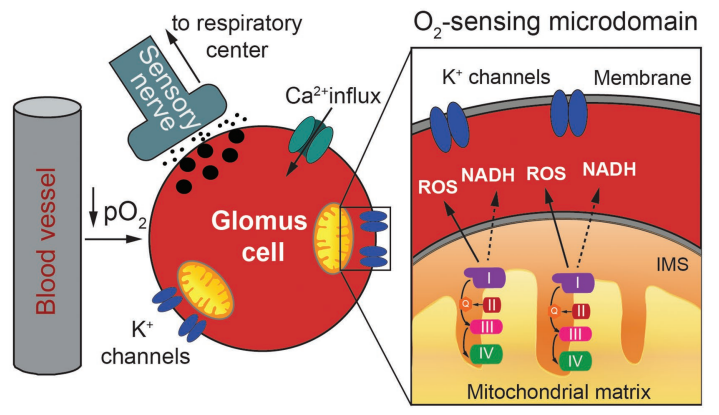

FIGURE 4 | Mitochondria-to-membrane signaling model of acute oxygen sensing by glomus cells. (A) Scheme illustrating the mitochondrial signals (NADH and ROS) generated upon exposure to hypoxia and their interaction with membrane ion channels. Modified from Moreno-Dominguez et al. (2020). (B) Model of chemosensory transduction by $\mathrm{O}_{2}$-sensing glomus cells in the carotid body. Modified from Fernandez-Aguera et al. (2015).

been reported. Genetic/developmental $\mathrm{CB}$ defects, such as congenital central hypoventilation syndrome (CCHS) and sudden infant death syndrome (SIDS) are life-threatening disorders partially related to alterations in CB function that, although rare in humans, can seriously impair $\mathrm{O}_{2}$-dependent respiratory control. CCHS is frequently associated with mutations in genes (such as RET or PHOX2B), which are relevant to development of neural crest-derived tissues (Amiel et al., 2003; Gaultier et al., 2004). Interestingly, CB glomus cells express high levels of GDNF (Villadiego et al., 2005), a neuroprotective dopaminotrophic factor that can activate RET, and genetic ablation of GDNF in adulthood results in a marked reduction in the number of TH-positive cells in the CB (Pascual et al., 2008). Decrease in size with reduction in the number of TH-positive cells and increased number of type II cells has been reported in CBs of autopsied CCHS (Cutz et al., 1997) and SIDS (Porzionato et al., 2013) patients. Prematurity and environmental factors, such as hyperoxia, retard maturation of $\mathrm{CB}$ chemoreceptors. Maternal smoking inhibits $\mathrm{CB}$ development and the excitability of AM chromaffin cells (Buttigieg et al., 2009).
The most frequent cause of $\mathrm{CB}$ inhibition is the use (or abuse) of anesthetics, myorelaxants, and analgesics. Volatile anesthetics (halothane and others) depress glomus cell excitability because they increase the open probability of background TASK1like $\mathrm{K}^{+}$channels (Buckler et al., 2000). Most of the myorelaxant drugs used in anesthesia are cholinergic antagonists, which interfere with the activation of the $\mathrm{CB}$ chemosensory synapse and inhibit the hypoxic ventilatory response (Jonsson et al., 2004). Endogenous opioids (enkephalins) are produced in the $\mathrm{CB}$, where they have an auto- or paracrine inhibitory effect (Kirby and McQueen, 1986). Systemic administration of opioids produces a strong respiratory depression, due in part to inhibition of peripheral chemoreceptors (Pokorski and Lahiri, 1981). However, opioid-induced respiratory depression (OIRD) in conscious rats is enhanced after bilateral CB denervation, suggesting a protective rather than causative role of the $\mathrm{CB}$ in OIRD (Baby et al., 2018). The design of well-tolerated drugs to activate peripheral chemoreceptors, which in turn stimulate the respiratory center, is a promising strategy to alleviate OIRD in humans; a clinical condition that has become a major health problem, particularly in the United States with a toll of over 150 deaths daily. In this regard, blockers of several types of $\mathrm{K}^{+}$channels are already being tested in the clinical setting as respiratory stimulants (Chokshi et al., 2015; Roozekrans et al., 2015). Within the context of this discussion, it is worth mentioning that these CB stimulants, which act downstream of the $\mathrm{O}_{2}$-sensing mechanism, might be useful to treat "silent hypoxemia," a bewildering frequent clinical manifestation found in patients with coronavirus disease 19 (COVID-19), who exhibit severe hypoxemia without clear signs of distress (dyspnea) or significant acceleration of breathing (Tobin et al., 2020). Given that in the early stages of coronavirus infection human cells undergo profound changes in the expression of mitochondrial proteins (Gordon et al., 2020), a plausible explanation for "silent hypoxemia" is the alteration of the mitochondria-based $\mathrm{O}_{2}$-sensor in coronavirus-infected $\mathrm{CB}$ glomus cells (Archer et al., 2020; Tobin et al., 2020). Another aspect of the MMS model of acute $\mathrm{O}_{2}$ sensing with translational relevance is the identification of the mitochondrial ETC as a potential pharmacological target to stimulate respiration. In this regard, it should be tested whether MCI inhibitors, such as metformin, one of the most broadly used drugs to treat type II diabetes (Protti, 2018), can activate the $\mathrm{CB}$ and stimulate respiration. It could be optimal to combine metformin with novel highly membrane permeant precursors of succinate (bis-1-acetoxy-ethyl succinate or diacetoxy-methyl succinate; Ehinger et al., 2016). We have shown that increased levels of ubiquinol $\left(\mathrm{CoQH}_{2}\right)$ resulting from the application of membrane permeant dimethyl succinate increases responsiveness to hypoxia (Arias-Mayenco et al., 2018). A combination of both therapies (metformin plus succinate prodrugs) would potentiate $\mathrm{CB}$ activation and at the same time prevent lactic acidosis secondary to metformin seen in some patients (Protti, 2018).

\section{Carotid Body Over-Activation}

Chronic activation of the $\mathrm{CB}$, as it occurs in patients with sleep apnea, metabolic syndrome or chronic left cardiac failure, due to intermittent hypoxia, high fat diet, or carotid 
hypoperfusion, respectively, can lead to exaggerated sympathetic outflow and autonomic dysfunction (see for review Ortega-Saenz and Lopez-Barneo, 2020). Although the pathophysiology of these maladaptive processes is still poorly known (Marcus et al., 2010; Paton et al., 2013; Schultz et al., 2013; Ribeiro et al., 2018), it has been shown in animal models that $\mathrm{CB}$ resection or deafferentation restores the sympathetic tone and improves the associated cardiovascular and metabolic alterations (Del Rio et al., 2013, 2016; McBryde et al., 2013; Ribeiro et al., 2013). However, translation of this therapy to the clinical setting has numerous limitations because the lack of $\mathrm{CB}$ may be cause of cardiovascular events, particularly during episodes of hypoxia and hypercapnia. CB resection could also have severe side effects such as altered glucose regulation or a reduced ability to acclimatize to high altitudes (Johnson and Joyner, 2013; Pijacka et al., 2018). In a pilot clinical trial performed on patients with chronic heart failure, bilateral $\mathrm{CB}$ ablation improved the autonomic imbalance but also increased the occurrence of nocturnal hypoxia, particularly in subjects with concomitant sleep apnea (Niewinski et al., 2017). An alternative to $\mathrm{CB}$ resection is the development of pharmacological drugs to selectively modulate $\mathrm{CB}$ chemosensory activity and plasticity. In this regard, it has been shown that a purinergic $\mathrm{P} 2 \mathrm{X} 3$ receptor blocker (AF-219) inhibits $\mathrm{CB}$ afferent activity and alleviates hypertension in a rat model (Pijacka et al., 2016). The translation of these findings to the clinical setting may be facilitated by the fact that purinergic $\mathrm{P} 2 \mathrm{X} 3$ receptor blockers (i.e., AF-219; also known as MK-7264 or Gefapixant) are already used in clinical trials to treat refractory chronic cough in humans, notwithstanding the unwanted side effect that taste sensation is also affected (Smith et al., 2020). A novel potential therapeutic option is represented by Hif2 antagonists, drugs already in clinical trials for the treatment of some types of cancer (Courtney et al., 2018; Fallah and Rini, 2019). Acute $\mathrm{O}_{2}$ sensing by glomus cells depends on Hif2 $\alpha$ (MorenoDominguez et al., 2020) and systemic administration of a Hif2 inhibitor (PT2385) results in inhibition of the HVR (Cheng et al., 2020). Moreover, Hif $2 \alpha$ is necessary for the proliferation of CB cells in hypoxia (Hodson et al., 2016) and activation of glomus cells is necessary for the proliferation and differentiation of $\mathrm{CB}$ progenitors and neuroblasts into mature $\mathrm{O}_{2}$-sensitive glomus cells (Platero-Luengo et al., 2014; Sobrino et al., 2018). Hence, Hif2 inhibitors may be beneficial to selectively modulate $\mathrm{CB}$ responsiveness to hypoxia and sympathetic over-activation.

\section{Carotid Body Tumorigenesis}

Chemodectomas are rare and mostly benign $\mathrm{CB}$ tumors that have attracted special attention because they are often used as a model to investigate the pathogenesis of paragangliomas (PGL), tumors generated in tissues of the peripheral nervous system derived from neural crest precursors. The most common cause of hereditary CB PGL is germ line mutations in genes coding subunits of mitochondrial succinate dehydrogenase (most frequently mutations in Sdhd and Sdhc; Baysal, 2008;
Her and Maher, 2015). Patients are heterozygous (with a normal and a mutated allele) and tumorigenesis is believed to be triggered by the loss of the normal allele (loss of heterozygosity) in $\mathrm{CB}$ glomus cells. However, the reasons why this allele is lost in some cell types (e.g., cells in CB and other paraganglia) and not in others as well as the mechanisms leading to tumor formation are unknown (MillanUcles et al., 2014). Given that the histology of CB PGL resembles that of hypertrophied $\mathrm{CBs}$ seen in chronically hypoxic subjects and that PGL incidence increases in populations living at high altitude (Astrom et al., 2003), a widely accepted hypothesis of tumor generation is the so called "pseudo hypoxic drive" (Selak et al., 2005; Smith et al., 2007). This hypothesis is based on the fact that succinate accumulation, secondary to succinate dehydrogenase dysfunction, causes downstream inhibition of prolyl hydroxylases involved in normal degradation of Hif as well as inhibition of histone demethylases and other enzymes, thereby causing cell proliferation. Indeed, overexpression of nondegradable Hif $2 \alpha$ (but not Hif $1 \alpha$ ) induces CB hypertrophy (Macias et al., 2014). Moreover, deletion of the gene coding for prolyl hydroxylase 2 in mice induces Hif $2 \alpha$-dependent CB glomus cell proliferation with a PGL-like phenotype (Fielding et al., 2018). However, experimental evidence indicates that unlike humans, heterozygosity for mutations in succinate dehydrogenase subunits does not predispose mice to PGL. Adult knockout mice heterozygous for Sdhd show practically normal CB function, with only a subtle glomus cell hyperplasia and organ hypertrophy (Piruat et al., 2004). In addition, conditional (embryonic or adult) bi-allelic ablation of $S d h d$ causes a marked glomus cell loss (Diaz-Castro et al., 2012). It seems therefore that in addition to succinate dehydrogenase subunit mutations, other hits, related to animal species, age, or cell metabolism, are necessary for tumorigenesis in vivo. Although there is convincing in vitro and in vivo evidence that multipotent stem cells contribute to $\mathrm{CB}$ angiogenesis and expansion of parenchyma during exposure to sustained hypoxia (Pardal et al., 2007; Annese et al., 2017), it has also been shown that proliferation of TH-positive cells greatly contributes to the growth of the glomus cell pool during the first 2-3 days of hypoxia (Paciga et al., 1999; Chen et al., 2007; Wang et al., 2008; Fielding et al., 2018). In the rat, and probably also in other species, this initial glomus cell expansion is due to proliferation and maturation of a population of TH-positive neuroblasts, which differentiate into $\mathrm{O}_{2}$-sensing glomus cells (Sobrino et al., 2018). Because hypoxia does not seem to induce proliferation of $\mathrm{CB}$ stem cells and undifferentiated progenitors in vitro (Platero-Luengo et al., 2014), a fundamental question that remains to be answered is whether hypoxia-induced release of transmitter and cytokines by mature glomus cells is a critical paracrine signal to trigger $\mathrm{CB}$ TH-positive cell proliferation and possibly the initial stages of tumor transformation. This would explain why Hif2 $\alpha$ stabilization increases $\mathrm{CB}$ growth and the expansion of $\mathrm{TH}$-positive cell population, and it would also support the use of Hif2 antagonists as potential therapeutic options to prevent $\mathrm{CB}$ PGL formation and growth. 


\section{CONCLUSIONS AND FUTURE DIRECTIONS}

The knowledge of $\mathrm{CB}$ physiology and the sensory function of glomus cells have steadily advanced in the last years. In addition to their well-established role as arterial $\mathrm{O}_{2} / \mathrm{CO}_{2}$ sensors, with a major impact on the regulation of respiration, glomus cells are now considered polymodal receptors with a wide physiological impact and able to detect and integrate changes in numerous chemical and physical variables in the blood. Although the molecular mechanisms underlying glomus cell acute responsiveness to hypoxia have remained elusive, the MMS model summarized in this paper has provided an unprecedented integrated view of glomus cell function that robustly explains most of the data available and, in addition, can be further tested experimentally. The progress in the understanding of the molecular physiology of acute $\mathrm{O}_{2}$ sensing by glomus cells, the prototypical $\mathrm{O}_{2}$ sensors, will surely boost advances in the identification and characterization of other acute $\mathrm{O}_{2}$ sensing cells in the body and in the investigation of their pathophysiological relevance. The MMS has also unraveled novel potential targets for pharmacological modulation of $\mathrm{CB}$ output that could be of therapeutic applicability in highly

\section{REFERENCES}

Amiel, J., Laudier, B., Attie-Bitach, T., Trang, H., de Pontual, L., Gener, B., et al. (2003). Polyalanine expansion and frameshift mutations of the pairedlike homeobox gene PHOX2B in congenital central hypoventilation syndrome. Nat. Genet. 33, 459-461. doi: 10.1038/ng1130

Annese, V., Navarro-Guerrero, E., Rodriguez-Prieto, I., and Pardal, R. (2017). Physiological plasticity of neural-crest-derived stem cells in the adult mammalian carotid body. Cell Rep. 19, 471-478. doi: 10.1016/j.celrep.2017.03.065

Aras, S., Pak, O., Sommer, N., Finley, R. Jr., Huttemann, M., Weissmann, N., et al. (2013). Oxygen-dependent expression of cytochrome $c$ oxidase subunit 4-2 gene expression is mediated by transcription factors RBPJ, CXXC5 and CHCHD2. Nucleic Acids Res. 41, 2255-2266. doi: 10.1093/nar/gks1454

Archer, S. L., Sharp, W. W., and Weir, E. K. (2020). Differentiating COVID-19 pneumonia from acute respiratory distress syndrome and high altitude pulmonary edema: therapeutic implications. Circulation 142, 101-104. doi: 10.1161/CIRCULATIONAHA.120.047915

Arias-Mayenco, I., Gonzalez-Rodriguez, P., Torres-Torrelo, H., Gao, L., Fernandez-Aguera, M. C., Bonilla-Henao, V., et al. (2018). Acute $\mathrm{O}_{2}$ sensing: role of coenzyme $\mathrm{QH} 2 / \mathrm{Q}$ ratio and mitochondrial ROS compartmentalization. Cell Metab. 28, 145-158. doi: 10.1016/j.cmet.2018.05.009

Astrom, K., Cohen, J. E., Willett-Brozick, J. E., Aston, C. E., and Baysal, B. E. (2003). Altitude is a phenotypic modifier in hereditary paraganglioma type 1: evidence for an oxygen-sensing defect. Hum. Genet. 113, 228-237. doi: 10.1007/s00439-003-0969-6

Baby, S. M., Gruber, R. B., Young, A. P., Macfarlane, P. M., Teppema, L. J., and Lewis, S. J. (2018). Bilateral carotid sinus nerve transection exacerbates morphine-induced respiratory depression. Eur. J. Pharmacol. 834, 17-29. doi: 10.1016/j.ejphar.2018.07.018

Balsa, E., Marco, R., Perales-Clemente, E., Szklarczyk, R., Calvo, E., Landazuri, M. O., et al. (2012). NDUFA4 is a subunit of complex IV of the mammalian electron transport chain. Cell Metab. 16, 378-386. doi: 10.1016/j.cmet.2012.07.015

Baysal, B. E. (2008). Clinical and molecular progress in hereditary paraganglioma. J. Med. Genet. 45, 689-694. doi: 10.1136/jmg.2008.058560

Benot, A. R., and Lopez-Barneo, J. (1990). Feedback inhibition of $\mathrm{Ca}^{2+}$ currents by dopamine in glomus cells of the carotid body. Eur. J. Neurosci. 2, 809-812. doi: $10.1111 / j .1460-9568.1990 . t b 00473 . x$ prevalent medical disorders presenting $\mathrm{CB}$ dysfunction. A more complete and comprehensive view of $\mathrm{CB}$ physiology will surely come from studies focusing on the mechanisms of $\mathrm{CB}$ plasticity and their impact on the pathogenesis of human diseases. In parallel, future research should also focus on the elucidation of the molecular bases of glomus cell responsiveness to stimuli, such as changes in blood glucose, lactate or flow, as well as in circulating hormones, which are still poorly known.

\section{AUTHOR CONTRIBUTIONS}

PO-S and JL-B prepared the first draft of the manuscript and figures. PO-S, JL-B, AM-D, and LG contributed to the writing of the final version of the paper. All authors contributed to the article and approved the submitted version.

\section{FUNDING}

This research was supported by the Spanish Ministries of Science and Innovation and Health (SAF2012-39343 and SAF2016-74990-R) and the European Research Council (ERC-ADGPRJ201502629).

Buckler, K. J., and Vaughan-Jones, R. D. (1994). Effects of hypoxia on membrane potential and intracellular calcium in rat neonatal carotid body type I cells. J. Physiol. 476, 423-428. doi: 10.1113/jphysiol.1994.sp020143

Buckler, K. J., Williams, B. A., and Honore, E. (2000). An oxygen-, acid- and anaesthetic-sensitive TASK-like background potassium channel in rat arterial chemoreceptor cells. J. Physiol. 525, 135-142. doi: 10.1111/j.1469-7793.2000.00135.x

Buttigieg, J., Brown, S., Holloway, A. C., and Nurse, C. A. (2009). Chronic nicotine blunts hypoxic sensitivity in perinatal rat adrenal chromaffin cells via upregulation of KATP channels: role of alpha7 nicotinic acetylcholine receptor and hypoxia-inducible factor-2alpha. J. Neurosci. 29, 7137-7147. doi: 10.1523/JNEUROSCI.0544-09.2009

Carroll, J., Ding, S., Fearnley, I. M., and Walker, J. E. (2013). Post-translational modifications near the quinone binding site of mammalian complex I. J. Biol. Chem. 288, 24799-24808. doi: 10.1074/jbc.M113.488106

Carroll, J., Fearnley, I. M., Skehel, J. M., Shannon, R. J., Hirst, J., and Walker, J. E. (2006). Bovine complex I is a complex of 45 different subunits. J. Biol. Chem. 281, 32724-32727. doi: 10.1074/jbc.M607135200

Chen, J., He, L., Liu, X., Dinger, B., Stensaas, L., and Fidone, S. (2007). Effect of the endothelin receptor antagonist bosentan on chronic hypoxia-induced morphological and physiological changes in rat carotid body. Am. J. Phys. Lung Cell. Mol. Phys. 292, L1257-L1262. doi: 10.1152/ajplung.00419.2006

Chen, Y., Tipoe, G. L., Liong, E., Leung, S., Lam, S. Y., Iwase, R., et al. (2002). Chronic hypoxia enhances endothelin-1-induced intracellular calcium elevation in rat carotid body chemoreceptors and up-regulates ETA receptor expression. Pflugers Arch. 443, 565-573. doi: 10.1007/s00424-001-0728-2

Cheng, X., Prange-Barczynska, M., Fielding, J. W., Zhang, M., Burrell, A. L., Lima, J. D., et al. (2020). Marked and rapid effects of pharmacological HIF-2 $\alpha$ antagonism on hypoxic ventilatory control. J. Clin. Invest. 130, 2237-2251. doi: 10.1172/JCI133194

Chokshi, R. H., Larsen, A. T., Bhayana, B., and Cotten, J. F. (2015). Breathing stimulant compounds inhibit TASK-3 potassium channel function likely by inding at a common site in the channel pore. Mol. Pharmacol. 88, 926-934. doi: 10.1124/mol.115.100107

Colgan, S. P., Furuta, G. T., and Taylor, C. T. (2020). Hypoxia and innate immunity: keeping up with the HIFsters. Annu. Rev. Immunol. 38, 341-363. doi: 10.1146/annurev-immunol-100819-121537

Courtney, K. D., Infante, J. R., Lam, E. T., Figlin, R. A., Rini, B. I., Brugarolas, J., et al. (2018). Phase I dose-escalation trial of PT2385, a first-in-class hypoxia- 
inducible factor- $2 \alpha$ antagonist in patients with previously treated advanced clear cell renal cell carcinoma. J. Clin. Oncol. 36, 867-874. doi: 10.1200/ JCO.2017.74.2627

Cutz, E., Ma, T. K., Perrin, D. G., Moore, A. M., and Becker, L. E. (1997). Peripheral chemoreceptors in congenital central hypoventilation syndrome. Am. J. Respir. Crit. Care Med. 155, 358-363. doi: 10.1164/ajrccm.155.1.9001336

Del Rio, R., Andrade, D. C., Lucero, C., Arias, P., and Iturriaga, R. (2016). Carotid body ablation abrogates hypertension and autonomic alterations induced by intermittent hypoxia in rats. Hypertension 68, 436-445. doi: 10.1161/HYPERTENSIONAHA.116.07255

Del Rio, R., Marcus, N. J., and Schultz, H. D. (2013). Carotid chemoreceptor ablation improves survival in heart failure: rescuing autonomic control of cardiorespiratory function. J. Am. Coll. Cardiol. 62, 2422-2430. doi: 10.1016/j. jacc.2013.07.079

Diaz-Castro, B., Pintado, C. O., Garcia-Flores, P., Lopez-Barneo, J., and Piruat, J. I. (2012). Differential impairment of catecholaminergic cell maturation and survival by genetic mitochondrial complex II dysfunction. Mol. Cell. Biol. 32, 3347-3357. doi: 10.1128/MCB.00128-12

Duchen, M. R., and Biscoe, T. J. (1992a). Mitochondrial function in type I cells isolated from rabbit arterial chemoreceptors. J. Physiol. 450, 13-31.

Duchen, M. R., and Biscoe, T. J. (1992b). Relative mitochondrial membrane potential and $\left[\mathrm{Ca}^{2+}\right] \mathrm{i}$ in type I cells isolated from the rabbit carotid body. J. Physiol. 450, 33-61.

Ehinger, J. K., Piel, S., Ford, R., Karlsson, M., Sjovall, F., Frostner, E. A., et al. (2016). Cell-permeable succinate prodrugs bypass mitochondrial complex I deficiency. Nat. Commun. 7:12317. doi: 10.1038/ncomms12317

Fallah, J., and Rini, B. I. (2019). HIF inhibitors: status of current clinical development. Curr. Oncol. Rep. 21:6. doi: 10.1007/s11912-019-0752-z

Fernandez-Aguera, M. C., Gao, L., Gonzalez-Rodriguez, P., Pintado, C. O., Arias-Mayenco, I., Garcia-Flores, P., et al. (2015). Oxygen sensing by arterial chemoreceptors depends on mitochondrial complex I signaling. Cell Metab. 22, 825-837. doi: 10.1016/j.cmet.2015.09.004

Fielding, J. W., Hodson, E. J., Cheng, X., Ferguson, D. J. P., Eckardt, L., Adam, J., et al. (2018). PHD2 inactivation in Type I cells drives HIF-2 $\alpha$-dependent multilineage hyperplasia and the formation of paraganglioma-like carotid bodies. J. Physiol. 596, 4393-4412. doi: 10.1113/JP275996

Fukuda, R., Zhang, H., Kim, J. W., Shimoda, L., Dang, C. V., and Semenza, G. L. (2007). HIF-1 regulates cytochrome oxidase subunits to optimize efficiency of respiration in hypoxic cells. Cell 129, 111-122. doi: 10.1016/j.cell.2007.01.047

Gao, L., Bonilla-Henao, V., Garcia-Flores, P., Arias-Mayenco, I., Ortega-Saenz, P., and Lopez-Barneo, J. (2017). Gene expression analyses reveal metabolic specifications in acute $\mathrm{O}_{2}$-sensing chemoreceptor cells. J. Physiol. 595, 6091-6120. doi: 10.1113/JP274684

Garcia-Fernandez, M., Mejias, R., and Lopez-Barneo, J. (2007). Developmental changes of chromaffin cell secretory response to hypoxia studied in thin adrenal slices. Pflugers Arch. 454, 93-100. doi: 10.1007/s00424-006-0186-y

Gaultier, C., Amiel, J., Dauger, S., Trang, H., Lyonnet, S., Gallego, J., et al. (2004). Genetics and early disturbances of breathing control. Pediatr. Res. 55, 729-733. doi: 10.1203/01.PDR.0000115677.78759.C5

Gordon, D. E., Jang, G. M., Bouhaddou, M., Xu, J., Obernier, K., White, K. M., et al. (2020). A SARS-CoV-2 protein interaction map reveals targets for drug repurposing. Nature 583, 459-468. doi: 10.1038/s41586-020-2286-9

He, L., Chen, J., Dinger, B., Sanders, K., Sundar, K., Hoidal, J., et al. (2002). Characteristics of carotid body chemosensitivity in NADPH oxidase-deficient mice. Am. J. Phys. Cell Phys. 282, C27-C33. doi: 10.1152/ajpcell.2002.282.1.C27

Her, Y. F., and Maher, L. J. 3rd. (2015). Succinate dehydrogenase loss in familial paraganglioma: biochemistry, genetics, and epigenetics. Int. J. Endocrinol. 2015:296167. doi: 10.1155/2015/296167

Hodson, E. J., Nicholls, L. G., Turner, P. J., Llyr, R., Fielding, J. W., Douglas, G., et al. (2016). Regulation of ventilatory sensitivity and carotid body proliferation in hypoxia by the PHD2/HIF-2 pathway. J. Physiol. 594, 1179-1195. doi: 10.1113/JP271050

Huttemann, M., Lee, I., Gao, X., Pecina, P., Pecinova, J., Liu, A. J., et al. (2012). Cytochrome $\mathrm{c}$ oxidase subunit 4 isoform 2-knockout mice show reduced enzyme activity, airway hyporeactivity, and lung pathology. FASEB J. 26, 3916-3930. doi: 10.1096/fi.11-203273

Johnson, B. D., and Joyner, M. J. (2013). Carotid body denervation: too soon to get breathless about heart failure? J. Am. Coll. Cardiol. 62, 2431-2432. doi: $10.1016 /$ j.jacc.2013.08.718
Jonsson, M., Wyon, N., Lindahl, S. G., Fredholm, B. B., and Eriksson, L. I. (2004). Neuromuscular blocking agents block carotid body neuronal nicotinic acetylcholine receptors. Eur. J. Pharmacol. 497, 173-180. doi: 10.1016/j. ejphar.2004.06.052

Kadenbach, B., and Huttemann, M. (2015). The subunit composition and function of mammalian cytochrome c oxidase. Mitochondrion 24, 64-76. doi: $10.1016 /$ j.mito.2015.07.002

Kang, D., Wang, J., Hogan, J. O., Vennekens, R., Freichel, M., White, C., et al. (2014). Increase in cytosolic $\mathrm{Ca}^{2+}$ produced by hypoxia and other depolarizing stimuli activates a non-selective cation channel in chemoreceptor cells of rat carotid body. J. Physiol. 592, 1975-1992. doi: 10.1113/jphysiol.2013. 266957

Kashani-Poor, N., Zwicker, K., Kerscher, S., and Brandt, U. (2001). A central functional role for the $49-\mathrm{kDa}$ subunit within the catalytic core of mitochondrial complex I. J. Biol. Chem. 276, 24082-24087. doi: 10.1074/jbc.M102296200

Kirby, G. C., and McQueen, D. S. (1986). Characterization of opioid receptors in the cat carotid body involved in chemosensory depression in vivo. British J. Pharmacol. 88, 889-898. doi: 10.1111/j.1476-5381.1986.tb16263.x

Kruse, S. E., Watt, W. C., Marcinek, D. J., Kapur, R. P., Schenkman, K. A., and Palmiter, R. D. (2008). Mice with mitochondrial complex I deficiency develop a fatal encephalomyopathy. Cell Metab. 7, 312-320. doi: 10.1016/j. cmet.2008.02.004

Lopez-Barneo, J. (1996). $\mathrm{O}_{2}$-sensing by ion channels and the regulation of cellular functions. Trends Neurosci. 19, 435-440. doi: 10.1016/S0166-2236(96) 10050-3

Lopez-Barneo, J., Benot, A., and Ureña, J. (1993). Oxygen sensing and the electrophysiology of arterial chemoreceptor cells. Physiology 8, 191-195.

Lopez-Barneo, J., Gonzalez-Rodriguez, P., Gao, L., Fernandez-Aguera, M. C., Pardal, R., and Ortega-Saenz, P. (2016). Oxygen sensing by the carotid body: mechanisms and role in adaptation to hypoxia. Am. J. Phys. Cell Phys. 310, C629-C642. doi: 10.1152/ajpcell.00265.2015

Lopez-Barneo, J., Lopez-Lopez, J. R., Urena, J., and Gonzalez, C. (1988). Chemotransduction in the carotid body: $\mathrm{K}^{+}$current modulated by $\mathrm{PO}_{2}$ in type I chemoreceptor cells. Science 241, 580-582. doi: 10.1126/science.2456613

Lopez-Barneo, J., and Simon, M. C. (2020). Cellular adaptation to oxygen deficiency beyond the Nobel award. Nat. Commun. 11:607. doi: 10.1038/ s41467-020-14469-9

Lucarelli, G., Rutigliano, M., Sallustio, F., Ribatti, D., Giglio, A., Lepore Signorile, M., et al. (2018). Integrated multi-omics characterization reveals a distinctive metabolic signature and the role of NDUFA4L2 in promoting angiogenesis, chemoresistance, and mitochondrial dysfunction in clear cell renal cell carcinoma. Aging 10, 3957-3985. doi: 10.18632/aging.101685

Macias, D., Cowburn, A. S., Torres-Torrelo, H., Ortega-Saenz, P., Lopez-Barneo, J., and Johnson, R. S. (2018). HIF-2 $\alpha$ is essential for carotid body development and function. elife 7:e34681. doi: 10.7554/eLife.34681

Macias, D., Fernandez-Aguera, M. C., Bonilla-Henao, V., and Lopez-Barneo, J. (2014). Deletion of the von Hippel-Lindau gene causes sympathoadrenal cell death and impairs chemoreceptor-mediated adaptation to hypoxia. EMBO Mol. Med. 6, 1577-1592. doi: 10.15252/emmm.201404153

Mahmoud, A. D., Lewis, S., Juricic, L., Udoh, U. A., Hartmann, S., Jansen, M. A., et al. (2016). AMP-activated protein kinase deficiency blocks the hypoxic ventilatory response and thus precipitates hypoventilation and apnea. Am. J. Respir. Crit. Care Med. 193, 1032-1043. doi: 10.1164/rccm.201508-1667OC

Marcus, N. J., Li, Y. L., Bird, C. E., Schultz, H. D., and Morgan, B. J. (2010). Chronic intermittent hypoxia augments chemoreflex control of sympathetic activity: role of the angiotensin II type 1 receptor. Respir. Physiol. Neurobiol. 171, 36-45. doi: 10.1016/j.resp.2010.02.003

McBryde, F. D., Abdala, A. P., Hendy, E. B., Pijacka, W., Marvar, P., Moraes, D. J., et al. (2013). The carotid body as a putative therapeutic target for the treatment of neurogenic hypertension. Nat. Commun. 4:2395. doi: 10.1038/ ncomms 3395

Meng, L., Yang, X., Xie, X., and Wang, M. (2019). Mitochondrial NDUFA4L2 protein promotes the vitality of lung cancer cells by repressing oxidative stress. Thorac. Cancer 10, 676-685. doi: 10.1111/1759-7714.12984

Millan-Ucles, A., Diaz-Castro, B., Garcia-Flores, P., Baez, A., Perez-Simon, J. A., Lopez-Barneo, J., et al. (2014). A conditional mouse mutant in the tumor suppressor SdhD gene unveils a link between p21(WAF1/Cip1) induction and mitochondrial dysfunction. PLoS One 9:e85528. doi: 10.1371/journal. pone. 0085528 
Mills, E., and Jobsis, F. F. (1972). Mitochondrial respiratory chain of carotid body and chemoreceptor response to changes in oxygen tension. J. Neurophysiol. 35, 405-428. doi: $10.1152 /$ jn.1972.35.4.405

Montoro, R., Ureña, J., Fernández-Chacón, R., Alvarez de Toledo, G., and López-Barneo, J. (1996). $\mathrm{O}_{2}$-sensing by ion channels and chemotransduction in single glomus cells. J. Gen. Physiol. 107, 133-143. doi: 10.1085/ jgp.107.1.133

Moreno-Dominguez, A., Ortega-Saenz, P., Gao, L., Colinas, O., Garcia-Flores, P., Bonilla-Henao, V., et al. (2020). Acute $\mathrm{O}_{2}$ sensing through HIF2 $\alpha$-dependent expression of atypical cytochrome oxidase subunits in arterial chemoreceptors. Sci. Signal. 13:eaay9452. doi: 10.1126/scisignal.aay 9452

Navarro-Guerrero, E., Platero-Luengo, A., Linares-Clemente, P., Cases, I., Lopez Barneo, J., and Pardal, R. (2016). Gene expression profiling supports the neural crest origin of adult rodent carotid body stem cells and identifies CD10 as a marker for mesectoderm-committed progenitors. Stem Cells 34, 1637-1650. doi: 10.1002/stem.2331

Niewinski, P., Janczak, D., Rucinski, A., Tubek, S., Engelman, Z. J., Piesiak, P., et al. (2017). Carotid body resection for sympathetic modulation in systolic heart failure: results from first-in-man study. Eur. J. Heart Fail. 19, 391-400. doi: 10.1002/ejhf.641

Nurse, C. (2014). Synaptic and paracrine mechanisms at carotid body arterial chemoreceptors. J. Physiol. 592, 3419-3426. doi: 10.1113/jphysiol.2013.269829

Obeso, A., Almaraz, L., and González, C. (1989). Effects of cyanide and uncouplers on chemoreceptor activity and ATP content of the cat carotid body. Brain Res. 481, 250-257. doi: 10.1016/0006-8993(89)90801-9

Ortega-Saenz, P., and Lopez-Barneo, J. (2020). Physiology of the carotid body: from molecules to disease. Annu. Rev. Physiol. 82, 127-149. doi: 10.1146/ annurev-physiol-020518-114427

Ortega-Saenz, P., Macias, D., Levitsky, K. L., Rodriguez-Gomez, J. A., Gonzalez-Rodriguez, P., Bonilla-Henao, V., et al. (2016). Selective accumulation of biotin in arterial chemoreceptors: requirement for carotid body exocytotic dopamine secretion. J. Physiol. 594, 7229-7248. doi: 10.1113/JP272961

Ortega-Saenz, P., Pardal, R., Garcia-Fernandez, M., and Lopez-Barneo, J. (2003). Rotenone selectively occludes sensitivity to hypoxia in rat carotid body glomus cells. J. Physiol. 548, 789-800. doi: 10.1113/jphysiol.2003.039693

Ortega-Saenz, P., Pascual, A., Gomez-Diaz, R., and Lopez-Barneo, J. (2006). Acute oxygen sensing in heme oxygenase-2 null mice. J. Gen. Physiol. 128, 405-411. doi: 10.1085/jgp.200609591

Paciga, M., Vollmer, C., and Nurse, C. (1999). Role of ET-1 in hypoxia-induced mitosis of cultured rat carotid body chemoreceptors. Neuroreport 10, 3739-3744. doi: 10.1097/00001756-199912160-00003

Pajuelo Reguera, D., Cunatova, K., Vrbacky, M., Pecinova, A., Houstek, J., Mracek, T., et al. (2020). Cytochrome c oxidase subunit 4 isoform exchange results in modulation of oxygen affinity. Cells 9:443. doi: 10.3390/cells 9020443

Pardal, R., Ludewig, U., Garcia-Hirschfeld, J., and Lopez-Barneo, J. (2000). Secretory responses of intact glomus cells in thin slices of rat carotid body to hypoxia and tetraethylammonium. Proc. Natl. Acad. Sci. U. S. A. 97, 2361-2366.

Pardal, R., Ortega-Saenz, P., Duran, R., and Lopez-Barneo, J. (2007). Glia-like stem cells sustain physiologic neurogenesis in the adult mammalian carotid body. Cell 131, 364-377. doi: 10.1016/j.cell.2007.07.043

Pascual, A., Hidalgo-Figueroa, M., Piruat, J. I., Pintado, C. O., Gomez-Diaz, R., and Lopez-Barneo, J. (2008). Absolute requirement of GDNF for adult catecholaminergic neuron survival. Nat. Neurosci. 11, 755-761. doi: 10.1038/ nn.2136

Paton, F. R., Sobotka, A., Fudim, M., Engelman, J., Hart, C. J., McBryde, D., et al. (2013). The carotid body as a therapeutic target for the treatment of sympathetically mediated diseases. Hypertension 61, 5-13. doi: 10.1161/ HYPERTENSIONAHA.111.00064

Peers, C. (1990). Hypoxic suppression of $\mathrm{K}^{+}$currents in type I carotid body cells: selective effect on the $\mathrm{Ca}^{2(+)}$-activated $\mathrm{K}^{+}$current. Neurosci. Lett. 119, 253-256. doi: 10.1016/0304-3940(90)90846-2

Peng, Y. J., Gridina, A., Wang, B., Nanduri, J., Fox, A. P., and Prabhakar, N. R. (2020). Olfactory receptor 78 participates in carotid body response to a wide range of low $\mathrm{O}_{2}$ levels but not to severe hypoxia. J. Neurophysiol. 123, 1886-1895. doi: 10.1152/jn.00075.2020

Peng, Y. J., Nanduri, J., Khan, S. A., Yuan, G., Wang, N., Kinsman, B., et al. (2011). Hypoxia-inducible factor $2 \alpha$ (HIF- $2 \alpha$ ) heterozygous-null mice exhibit exaggerated carotid body sensitivity to hypoxia, breathing instability, and hypertension. Proc. Natl. Acad. Sci. U. S. A. 108, 3065-3070. doi: 10.1073/ pnas. 1100064108

Pijacka, W., Katayama, P. L., Salgado, H. C., Lincevicius, G. S., Campos, R. R., McBryde, F. D., et al. (2018). Variable role of carotid bodies in cardiovascular responses to exercise, hypoxia and hypercapnia in spontaneously hypertensive rats. J. Physiol. 596, 3201-3216. doi: 10.1113/JP275487

Pijacka, W., Moraes, D. J., Ratcliffe, L. E., Nightingale, A. K., Hart, E. C., da Silva, M. P., et al. (2016). Purinergic receptors in the carotid body as a new drug target for controlling hypertension. Nat. Med. 22, 1151-1159. doi: $10.1038 / \mathrm{nm} .4173$

Piruat, J. I., Pintado, C. O., Ortega-Saenz, P., Roche, M., and Lopez-Barneo, J. (2004). The mitochondrial SDHD gene is required for early embryogenesis, and its partial deficiency results in persistent carotid body glomus cell activation with full responsiveness to hypoxia. Mol. Cell. Biol. 24, 10933-10940. doi: 10.1128/MCB.24.24.10933-10940.2004

Platero-Luengo, A., Gonzalez-Granero, S., Duran, R., Diaz-Castro, B., Piruat, J. I., Garcia-Verdugo, J. M., et al. (2014). An $\mathrm{O}_{2}$-sensitive glomus cell-stem cell synapse induces carotid body growth in chronic hypoxia. Cell 156, 291-303. doi: $10.1016 /$ j.cell.2013.12.013

Pokorski, M., and Lahiri, S. (1981). Effects of naloxone on carotid body chemoreception and ventilation in the cat. J. Appl. Physiol. Respir. Environ. Exerc. Physiol. 51, 1533-1538. doi: 10.1152/jappl.1981.51.6.1533

Porzionato, A., Macchi, V., Stecco, C., and De Caro, R. (2013). The carotid body in sudden infant death syndrome. Respir. Physiol. Neurobiol. 185, 194-201. doi: 10.1016/j.resp.2012.05.013

Protti, A. (2018). Succinate and the shortcut to the cure of metformin-induced lactic acidosis. Intensive Care Med. Exp. 6:35. doi: 10.1186/s40635-018-0202-5

Rakoczy, R. J., and Wyatt, C. N. (2018). Acute oxygen sensing by the carotid body: a rattlebag of molecular mechanisms. J. Physiol. 596, 2969-2976. doi: $10.1113 /$ JP274351

Ratcliffe, P. J. (2013). Oxygen sensing and hypoxia signalling pathways in animals: the implications of physiology for cancer. J. Physiol. 591, 2027-2042. doi: 10.1113 /jphysiol.2013.251470

Ribeiro, M. J., Sacramento, J. F., Gallego-Martin, T., Olea, E., Melo, B. F., Guarino, M. P., et al. (2018). High fat diet blunts the effects of leptin on ventilation and on carotid body activity. J. Physiol. 596, 3187-3199. doi: 10.1113/JP275362

Ribeiro, M. J., Sacramento, J. F., González, C., Guarino, M. P., Monteiro, E. C., and Conde, S. V. (2013). Carotid body denervation prevents the development of insulin resistance and hypertension induced by hypercaloric diets. Diabetes 62, 2905-2291. doi: 10.2337/db12-1463

Rieger, B., Shalaeva, D. N., Sohnel, A. C., Kohl, W., Duwe, P., Mulkidjanian, A. Y., et al. (2017). Lifetime imaging of GFP at CoxVIIIa reports respiratory supercomplex assembly in live cells. Sci. Rep. 7:46055. doi: 10.1038/srep46055

Rong, W., Gourine, A. V., Cockayne, D. A., Xiang, Z., Ford, A. P., Spyer, K. M., et al. (2003). Pivotal role of nucleotide P2X2 receptor subunit of the ATPgated ion channel mediating ventilatory responses to hypoxia. J. Neurosci. 23, 11315-11321. doi: 10.1523/JNEUROSCI.23-36-11315.2003

Roozekrans, M., Olofsen, E., Van Der Schrier, R., Van Gerven, J., Peng, S., Mcleod, J., et al. (2015). Reversal of opioid-induced respiratory depression by BK-channel blocker GAL021: a pharmacokinetic-pharmacodynamic modeling study in healthy volunteers. Clin. Pharmacol. Ther. 97, 641-649. doi: $10.1002 /$ cpt.99

Schultz, H. D., Marcus, N. J., and Del Rio, R. (2013). Role of the carotid body in the pathophysiology of heart failure. Curr. Hypertens. Rep. 15, 356-362. doi: 10.1007/s11906-013-0368-x

Selak, M. A., Armour, S. M., Mackenzie, E. D., Boulahbel, H., Watson, D. G., Mansfield, K. D., et al. (2005). Succinate links TCA cycle dysfunction to oncogenesis by inhibiting HIF-alpha prolyl hydroxylase. Cancer Cell 7, 77-85. doi: 10.1016/j.ccr.2004.11.022

Semenza, G. L. (2014). Oxygen sensing, hypoxia-inducible factors, and disease pathophysiology. Annu. Rev. Pathol. 9, 47-71. doi: 10.1146/annurevpathol-012513-104720

Shirahata, M., Balbir, A., Otsubo, T., and Fitzgerald, R. S. (2007). Role of acetylcholine in neurotransmission of the carotid body. Respir. Physiol. Neurobiol. 157, 93-105. doi: 10.1016/j.resp.2006.12.010

Smith, E. H., Janknecht, R., and Maher, L. J. 3rd. (2007). Succinate inhibition of alpha-ketoglutarate-dependent enzymes in a yeast model of paraganglioma. Hum. Mol. Genet. 16, 3136-3148. doi: 10.1093/hmg/ddm275 
Smith, J. A., Kitt, M. M., Morice, A. H., Birring, S. S., McGarvey, L. P., Sher, M. R., et al. (2020). Gefapixant, a P2X3 receprtor antagonist, for the treatment of refractory or unexplained chornic cough: a ramdomised, double blind, controlled, parallel-group, phase $2 \mathrm{~b}$ trial. Lancet Respir. Med. 8, 775-785. doi: 10.1016/S2213-2600(19)30471-0

Sobrino, V., Gonzalez-Rodriguez, P., Annese, V., Lopez-Barneo, J., and Pardal, R. (2018). Fast neurogenesis from carotid body quiescent neuroblasts accelerates adaptation to hypoxia. EMBO Rep. 19:e44598. doi: 10.15252/embr.20 1744598

Sommer, N., Huttemann, M., Pak, O., Scheibe, S., Knoepp, F., Sinkler, C., et al. (2017). Mitochondrial complex IV subunit 4 isoform 2 is essential for acute pulmonary oxygen sensing. Circ. Res. 121, 424-438. doi: 10.1161/ CIRCRESAHA.116.310482

Taylor, S. C., Shaw, S. M., and Peers, C. (2000). Mitochondrial inhibitors evoke catecholamine release from pheochromocytoma cells. Biochem. Biophys. Res. Commun. 273, 17-21. doi: 10.1006/bbrc.2000.2894

Tello, D., Balsa, E., Acosta-Iborra, B., Fuertes-Yebra, E., Elorza, A., Ordonez, A., et al. (2011). Induction of the mitochondrial NDUFA4L2 protein by HIF-1alpha decreases oxygen consumption by inhibiting complex I activity. Cell Metab. 14, 768-779. doi: 10.1016/j.cmet.2011.10.008

Tian, H., Hammer, R. E., Matsumoto, A. M., Russell, D. W., and Mcknight, S. L. (1998). The hypoxia-responsive transcription factor EPAS1 is essential for catecholamine homeostasis and protection against heart failure during embryonic development. Genes Dev. 12, 3320-3324. doi: 10.1101/gad.12.21.3320

Timmers, H. J., Karemaker, J. M., Wieling, W., Marres, H. A., Folgering, H. T., and Lenders, J. W. (2003). Baroreflex and chemoreflex function after bilateral carotid body tumor resection. J. Hypertens. 21, 591-599. doi: 10.1097/ 00004872-200303000-00026

Tobin, M. J., Laghi, F., and Jubran, A. (2020). Why COVID-19 silent hypoxemia is baffling to physicians. Am. J. Respir. Crit. Care Med. 202, 356-360. doi: 10.1164/rccm.202006-2157CP

Torres-Torrelo, H., Ortega-Saenz, P., Macias, D., Omura, M., Zhou, T., Matsunami, H., et al. (2018). The role of Olfr78 in the breathing circuit of mice. Nature 561, E33-E40. doi: 10.1038/s41586-018-0545-9

Tsukihara, T., Aoyama, H., Yamashita, E., Tomizaki, T., Yamaguchi, H., Shinzawa-Itoh, K., et al. (1996). The whole structure of the 13-subunit oxidized cytochrome c oxidase at 2.8 A. Science 272, 1136-1144. doi: 10.1126/ science. 272.5265 .1136

Urena, J., Fernandez-Chacon, R., Benot, A. R., Alvarez De Toledo, G. A., and Lopez-Barneo, J. (1994). Hypoxia induces voltage-dependent $\mathrm{Ca}^{2+}$ entry and quantal dopamine secretion in carotid body glomus cells. Proc. Natl. Acad. Sci. U. S. A. 91, 10208-10211.

Varas, R., Wyatt, C. N., and Buckler, K. J. (2007). Modualtion of TASK-like background potassium channels in rat arterial chemoreceptor cells by intracellular ATP and other nucelotides. J. Physiol. 583, 521-536. doi: 10.1113/ jphysiol.2007.135657

Villadiego, J., Mendez-Ferrer, S., Valdes-Sanchez, T., Silos-Santiago, I., Farinas, I., Lopez-Barneo, J., et al. (2005). Selective glial cell line-derived neurotrophic factor production in adult dopaminergic carotid body cells in situ and after intrastriatal transplantation. J. Neurosci. 25, 4091-4098. doi: 10.1523/ JNEUROSCI.4312-04.2005

Wang, J., Hogan, J. O., Wang, R., White, C., and Kim, D. (2017). Role of cystathionine-gamma-lyase in hypoxia-induced changes in TASK activity, intracellular $\left[\mathrm{Ca}\left({ }^{2+}\right)\right]$ and ventilation in mice. Respir. Physiol. Neurobiol. 246, 98-106. doi: $10.1016 /$ j.resp.2017.08.009
Wang, Y., Li, Z., Zhang, X., Xiang, X., Li, Y., Mulholland, M. W., et al. (2016). Nesfatin-1 promotes brown adipocyte phenotype. Sci. Rep. 6:34747. doi: $10.1038 /$ srep34747

Wang, Z. Y., Olson, E. B. Jr., Bjorling, D. E., Mitchell, G. S., and Bisgard, G. E. (2008). Sustained hypoxia-induced proliferation of carotid body type I cells in rats. J. Appl. Physiol. 104, 803-808. doi: 10.1152/japplphysiol.00393.2007

Waypa, G. B., Marks, J. D., Guzy, R., Mungai, P. T., Schriewer, J., Dokic, D., et al. (2010). Hypoxia triggers subcellular compartmental redox signaling in vascular smooth muscle cells. Circ. Res. 106, 526-535. doi: 10.1161/ CIRCRESAHA.109.206334

Weir, E. K., Lopez-Barneo, J., Buckler, K. J., and Archer, S. L. (2005). Acute oxygen-sensing mechanisms. New Engl. J. Med. 353, 2042-2055. doi: 10.1056/ NEJMra050002

Wilson, D. F., Mokashi, A., Chugh, D., Vinogradov, S., Osanai, S., and Lahiri, S. (1994). The primary oxygen sensor of the cat carotid body is cytochrome a3 of the mitochondrial respiratory chain. FEBS Lett. 351, 370-374. doi: 10.1016/0014-5793(94)00887-6

Wu, M., Gu, J., Guo, R., Huang, Y., and Yang, M. (2016). Structure of mammalian respiratory supercomplex I1III2IV1. Cell 167, 1598-1609. doi: 10.1016/j. cell.2016.11.012

Wyatt, C. N., and Buckler, K. J. (2004). The effect of mitochondrial inhibitors on membrane currents in isolated neonatal rat carotid body type I cells. J. Physiol. 556, 175-191. doi: 10.1113/jphysiol.2003.058131

$\mathrm{Xu}$, J., Tse, F. W., and Tse, A. (2003). ATP triggers intracellular $\mathrm{Ca}^{2+}$ release in type II cells of the rat carotid body. J. Physiol. 549, 739-747. doi: 10.1113/ jphysiol.2003.039735

Zhang, M., Piskuric, N. A., Vollmer, C., and Nurse, C. A. (2012). P2Y2 receptor activation opens pannexin-1 channels in rat carotid body type II cells: potential role in amplifying the neurotransmitter ATP. J. Physiol. 590, 4335-4350. doi: 10.1113/jphysiol.2012.236265

Zhang, M., Vollmer, C., and Nurse, C. A. (2018). Adenosine and dopamine oppositely modulate a hyperpolarization-activated current Ih in chemosensory neurons of the rat carotid body in co-culture. J. Physiol. 596, 3101-3117. doi: $10.1113 / J P 274743$

Zhang, M., Zhong, H., Vollmer, C., and Nurse, C. A. (2000). Co-release of ATP and ACh mediates hypoxic signalling at rat carotid body chemoreceptors. J. Physiol. 525, 143-158. doi: 10.1111/j.1469-7793.2000.t01-1-00143.x

Zhong, H., Zhang, M., and Nurse, C. A. (1997). Synapse formation and hypoxic signalling in co-cultures of rat petrosal neurones and carotid body type 1 cells. J. Physiol. 503, 599-612. doi: 10.1111/j.1469-7793.1997.599bg.x

Zhou, T., Chien, M. S., Kaleem, S., and Matsunami, H. (2016). Single cell transcriptome analysis of mouse carotid body glomus cells. J. Physiol. 594, 4225-4251. doi: 10.1113/JP271936

Conflict of Interest: The authors declare that the research was conducted in the absence of any commercial or financial relationships that could be construed as a potential conflict of interest.

Copyright (๑) 2020 Ortega-Sáenz, Moreno-Dominguez, Gao and López-Barneo. This is an open-access article distributed under the terms of the Creative Commons Attribution License (CC BY). The use, distribution or reproduction in other forums is permitted, provided the original author(s) and the copyright owner $(s)$ are credited and that the original publication in this journal is cited, in accordance with accepted academic practice. No use, distribution or reproduction is permitted which does not comply with these terms. 